DOI https://doi.org/10.36059/978-966-397-192-6/113-125

\title{
PART 6. RELIGION AND CHURCH IN CARPATHIAN UKRAINE
}

The long-standing national liberation struggle of Transcarpathian Ukrainians for their autonomous rights ended with their acquisition in October 1938, when the Prague political power appointed Andriy Brodi as the head of the local government, and soon it appointed Avhustyn Voloshyn. On February 12, 1939, elections to the Soim of Carpathian Ukraine were held, after what it declared full independence on March 15. These vivid and dignified events were caused by Ukrainian political parties, various patriotic societies, including "Prosvita", a number of well-known socio-political figures of the region, who throughout the interwar period advocated the Ukrainian idea, defended the right of the local population to have their own statehood. An important role in these processes was played by the Greek Catholic Church, which for several decades has brought up a whole pleiad of bright personalities, including the President of Carpathian Ukraine, Auvhustyn Voloshyn, patriotic Ukrainian priests and cultural and educational figures Kyrylo Fedelesh, Stepan Sabol (Zoreslav), Karlo Kupar, Yuri Stanynets and many others. At the same time, it should be noted that some Transcarpathian priests did not support the Ukrainian idea and openly campaigned against it. Often, they fought openly against the autonomous government of Avhustyn Voloshyn Voloshyn, and supported the idea of entering Transcarpathia into Horthy's Hungary. With the occupation of the Carpathian Ukraine by the Hungarian troops, mass repressions against its defenders began. The clergy also went through this.

Taking into account the fact that the true history of the church in Transcarpathia was forbidden before the proclamation of Ukraine's independence, the first objective scientific publications appeared abroad. Their authors mainly were active participants in the national liberation competitions of 1938-1939, who immigrated to the countries of Europe and America after the occupation of Transcarpathia by the Horthy's troops. Comprehensive monographs on the above-mentioned events were published by V. Shandor, A. Shtefan, S. Rosokha and Y. Khymynets. A huge factual material is contained in the memoirs and in a published diary of V. Grendzha-Donsky, the editor-in-chief of the governmental newspaper "Nova Svoboda". Among the historians of the Ukrainian diaspora in the United States who have been researching the history of the Greek Catholic Church of the Carpathian Ukraine for many years, we should mention P. Sterch, O. Danko, V. Markus, P.R. Magocsi, A. Pekar, M. Utrysk, 
I. Lysiak-Rudnytsky and others. In Ukraine, the aforementioned problem is most fully reflected in the pages of the three-volume work "Essays on the History of Transcarpathia", which was published in the early 1990s under the editorship of Professor I. Hranchak. Unfortunately, more space in it was given not so much to Carpathian Ukraine as to the religious situation in Transcarpathia during the interwar period. This issue is most fully researched in the monographs and articles by $M$. Boldyzhar and M. Palinchak. Issues of religion and church in the times of Carpathian Ukraine were investigated by P. Chuchka, O. Khlanta, N. Benjko and O. Dovhanych. The authors of the monographs on the life path and social and political activity of Auvhustyn Voloshyn were M. Tokar, M. Zymomrya, V. Homonnai, M. Klyap, V. Turyanytsya, V. Serhiychuk. Avhustyn Voloshyn's relationships with Metropolitan Andrey Sheptytsky were explored by O. Khomenko and V. Basarab. The multifaceted activity of Dionisije Njaradi was researched by I. Likhtey.

The main purpose is to investigate the main aspects of the churchreligious situation in the Carpathian Ukraine in the late 1930s, when the young state underwent a sort of evolution from autonomy to declaration of complete independence. Considerable attention is paid to the relationship between representatives of the Orthodox and Greek Catholic Churches, the activities of the most prominent representatives of the clergy of Transcarpathia - Avhustyn Voloshyn, Dionisije Njaradi and Olexandr Stoyka.

In the late 1930s, the Greek Catholic Church in non-Soviet Ukraine counted 4.370 .000 believers, 3.040 parishes with 4.440 churches. In five eparchies with two Apostolic Administrators there were two bishops and one metropolitan. According to the calculations of I. Ortynsky, there were 2.950 priests, 520 hieromonks (priests-monks), 1.100 nuns, 540 students of theology, 4 small seminaries, 41 Catholic organizations and 38 magazines, jornals and publishers in Western Ukraine ${ }^{318}$. There were 410.000 Greek Catholics in Transcarpathia ${ }^{319}$.

In 1936, 140.000 Orthodox believers were registered in the land, they were served by 67 church representatives (15 nuns and 52 priests) ${ }^{320}$. According to V. Markusj, "the movement of Orthodoxy began in the Czechoslovakia in the 1920-30's, and soon the Greek Catholic Church lost its monopoly position among the Ukrainians. Orthodoxy spread on the

\footnotetext{
${ }^{318}$ Оршан Я. Закарпаття. Париж, 1938. С. 118.

319 Стерчо П. Карпато-Українська держава: 3 історії визвольної боротьби карпатських українців у 1919-1939 роках. Торонто, 1965; Львів: За вільну Україну, 1994. С. 85.

${ }_{320}$ Палінчак М. Державно-церковні відносини на Закарпатті та в Східній Галичині в 20 - середині 30-х років XX століття. Ужгород, 1996. С. 47.
} 
initiative of mainly Russian, as well as Bukovynian and Galician Russophile, emigrants, and thanks to the support of the Prague government, which saw in the new religious movement a reaction to the political course of the Magyarized Greek Catholic clergy"321. The first Serbian bishop in Transcarpathia was Dosifeus, later Vladimir, whom the Hungarians removed after occupation.

On November 2, 1938, the Vienna Arbitration took place, leaving 35 Greek Catholic parishes, led by Bishop O. Stoyka, who remained in Uzhgorod, under Hungary ${ }^{322}$. Thus, in Carpathian Ukraine, there were 280 parishes left without a bishop ${ }^{323}$. As early as November 3, 1938, a memorandum was drawn up on behalf of the Mukachevo Greek Catholic eparchy and a number of political parties and associations, which was transmitted to the governments of Czechoslovakia, the United Kingdom, France, Germany, Italy, Poland, Romania, Hungary and Yugoslavia. It stated that "the Vienna arbitration has taken away from the Carpathian Rus the main city of Uzhgorod and the industrial center of Mukachevo, without which the land cannot exist in economic, cultural and national terms. Therefore, we declare that even after the Vienna Arbitration, we consider this territory a single and inceparable» ${ }^{324}$. This memorandum had no effect on the initiators of the arbitration in Vienna and it has a symbolic meaning. Bishop O. Stoyka made an attempt to subjugate Greek-Catholic parishes of the Carpathian Ukraine. He sent the youngest canonist Ludovic Minya to Khust so he could manage 280 parishes. The Vatican, of course, did not take that step.

In the current situation, Dionisije Njaradi, bishop of the Greek Catholic Eparchy of Krizevci, took the initiative and "gave a memorandum to the hands of Cardinal Eugene Tisserant, Secretary of the Congregation for the Eastern Church in Rome, informing that in Carpathian Ukraine more than 400.000 believers remain without a bishop"325. On November 14, 1938, Pope Pius XI met D. Njaradi at his audience, during which he instructed him

${ }^{321}$ Маркусь В. Нищення греко-католицької церкви в Мукачівській єпархії в 19451950 pр. Відбитка із Збірника присвяченого памяті 3. Кузелі. Записки НТШ. Т. СХІХ. Париж, 1982. С. 5.

${ }^{322}$ Бенько Н. Міжконфесійні відносини на Закарпатті в політичних подіях 1938-1949 pp. Науковий збірник Закарпатського краєзнавчого музею. Випуск другий. Ужгород, 1996. C. 103-119.

323 Магочій П. Р. Формування національної самосвідомості: Підкарпатська Русь (1848-1948). Ужгород, 1994. С. 15.

${ }^{324}$ Довганич О. Д., Пашкуй 3. А., Троян М. В. Закарпаття в роки війни. Ужгород: Карпати, 1990. С. 18.

${ }^{325}$ Стерчо П. Карпато-Українська держава: 3 історії визвольної боротьби карпатських українців у 1919-1939 роках. Торонто, 1965; Львів: За вільну Україну, 1994. С. 84. 
to "take care of the poorest people of the Subcarpathian region, left without a shepherd and other necessary means" ${ }^{326}$. On November 15, 1938, Cardinal E. Tisserant on behalf of the Holy Congregation of the Eastern Church in Vatican issued a decree No. 653/38, according to which "the jurisdiction of the Most Holy Olexandr Stoyka, Rusyn Bishop of Mukachevo,begins in the parishes oh his diocese, which are placed beyond the borders of the Hungarian Kingdom, until the Apostolic Capital decides otherwise. All other decisions, contrary to this, are hereby canceled"327. The reason for such Vatican's move was explained by the effects of the Vienna Arbitration, after which "a new distinction was made between the Czechoslovak Republic and the Kingdom of Hungary" and "most of the Parishes of the Mukachevo Diocese of Rusyns were, in fact, excommunicated from the cities of Mukachevo and Uzhgorod" 328 . Due to the fact that "Mukachevo Bishop of Rusyns has no possibility to get from one part (diocese) to another within his jurisdiction", the Vatican has "commissioned the High Blessed Dr. Dionisije Njaradi, the Bishop of Krizevci, to overtake the power of the Apostolic Visitator of the Mukachevo eparchy of Rusyns, who are in the Czechoslovak Republic, and to inform the Apostolic Capital on everything,329.

As early as 1934, "Blahovisnyk" reported that in the near future a new Greek Catholic bishopric should be established in Khust. This would allow the Vatican to turn the Eparchy of Uzhgorod into a Metropoly. However, the governmental message of the Apostolic Capital in this case came as early as September 2, 1937. World War II crossed out these credible plans. Regarding the appointment of D. Njaradi as apostolic administrator of the region, this act of the Vatican was considered only as temporary, "in anticipation of the creation of own Transcarpathian metropoly" ${ }^{330}$. In an interview with the newspaper "Nova Svoboda" on December 12, 1938, D. Njaradi said: "There are, therefore, two eparchies, and ours still will be governed by the apostolic administration, maybe for a long time... According to my guess, the eparchy of Carpathian Ukraine will eventually become definitively separate, because it can already be said that the Eparchy of Mukachevo became two separate eparchies. The residence of the apostolic

${ }^{326}$ Ibid. C. 84-85.

${ }^{327}$ Нова свобода. 1938. 6 грудня.

${ }^{328}$ Ibid.

${ }^{329}$ Нова свобода. 1938. 6 грудня.

${ }_{330}$ Пекар А. Мукачівська Єпархія і Галицька митрополія. Украӥнські Карпати: етнос, історія, культура. Матеріали міжнародної наукової конференції. Ужгород: Карпати, 1993. C. 402. 
administration is now in Khust and I think that the location of the eparchy will be in the Capital of the Government of Carpathian Ukraine" 331 .

It is necessary to agree with the assertion of P. R. Magocsi that "since Njaradi was a well-known Ukrainophile, such appointment testified that the Vatican recognized the Ukrainian orientation of the autonomous government" ${ }^{332}$. At that time Carpathian Ukraine was becoming the center of the struggle not only political but also ecclesiastical. It was not accidentally that A. Voloshyn in the "Manifesto of the Government of Carpathian Ukraine to all citizens of Carpathian Ukraine" (November 3, 1938) called for next: "Let all the religious and class disputes, which the enemies of our people have caused between us, today disappear"333. In the deep conviction of V. Shandor, "with the appointment of Bishop Njaradi as an apostolic administrator in Khust, the Greek Catholic Church from the side of jurisdiction was regulated well" ${ }^{334}$. What about Hungary, it expressed its dissatisfaction with the Vatican's appointment of Njaradi as the bishop of Carpathian Ukraine.

The Ministry of Foreign Affairs of the Czechoslovak Republic informed A. Voloshyn's government on November 26, 1938 about the arrival of D. Njaradi in the Carpathian Ukraine. "This news," as "Nova svoboda" wrote, "caused great satisfaction to the people of the Carpathian Ukraine" 335 . On November 29, Khust met Bishop D. Njaradi, who came from the Vatican through Yugoslavia ${ }^{336}$. On December 4, 1938, he held the first Divine service in Khust, proclaiming the liturgy "for an independent Carpathian Ukraine, for its people, for the Government and for its good - to be all for one! One thing: in Catholicism, in Ukrainian nationality, all in a noble work, in culture: in short, one thing in life and death!" ${ }^{337}$. So, from the very first days of his stay in Carpathian Ukraine, D. Njaradi established himself as a sincere supporter of the Ukrainian idea.

The bishop's Ukrainian orientation is clearly reflected in his "Pastoral Letters" and "Appeals". In one of his first Pastoral Letters, D. Njaradi said: "I ask all the Fathers to have a Divine service during the week, if there are no other intentions, to the Holy Father's intention: "About the peace of the

\footnotetext{
${ }^{331}$ Нова свобода. 1938. 13 грудня.

332 Магочій П. Р. Формування національної самосвідомості: Підкарпатська Русь (1848-1948). Ужгород, 1994. С. 115.

333 Волошин А. Початки національного пробудження на Підкарпатській Русі. Августин Волошин. Твори. Ужгород: Гражда, 1995. С. 113-116.

334 Шандор В. Спомини. Т. 1. Карпатська Україна. 1938-1939. Ужгород: МПП «Гражда»; Карпатський Союз, 1996. С. 257.

${ }_{335}^{335}$ Нова свобода. 1938. 27 листопада.

${ }^{336}$ Ibid. 30 листопада.

${ }^{337}$ Ibid. 4 грудня.
} 
whole world", but also for the good of our state. At the same time, I very much entrust all my Faithful people in their prayers to ask for blessings for our whole people, and above all for those in whose hands the God's Providence has given the power to govern our state and our people" ${ }^{338}$. On December 18, 1938, D. Njaradi visited Perechyn, where he delivered a speech in which he "urged believers to stand with confidence by the faith, that only in some faith is our salvation and the success of our revival and the better future of our nation and state liberation"339. In the "Pastoral Letter" of December 23, 1938, D. Njaradi informed the believers that "I gave our eparchy of Mukachevo in the Czechoslovak Republic under the special care of Virgin Mary, and our state proclaimed her a special Patroness-Protector of Subcarpathian State" ${ }^{\prime 40}$.

On January 1, 1939, the bishop addressed the "Father's Friendly Word to Fathers, Shepherds of the Soul", in which he asked them "to be aware of their sacred tasks, to keep themselves away from any anti-state agitation, so that even the smallest shadow would not fall on their activities. Both ecclesiastical law and natural law show us, the shepherds of the souls, which must be our relation to the lawful Authority in the territory in which we have to develop our priestly activity. We must take a positive position towards such a government..." ${ }^{341}$. Despite this warning, Greek Catholic priests N. Silvaj, I. Josyph, Z. Sholtes, I. Minj and I. Emeryk were detained by the Ukrainian police. They were accused of anti-Czech, anti-Ukrainian and proHungarian propaganda and were imprisoned in the Dumen concentration camp. Undoubtedly, the above mentioned persons did not complete the list of priests who openly worked for Hungary. Perhaps that is why some members of the government of the Carpathian Ukraine have made proposals to replace priests in some districts ${ }^{342}$.

Having begun to perform the duties of an apostolic administrator in Carpathian Ukraine, D. Njaradi outlined his program of actions in an interview with the editor of "Nova Svoboda" V. Grenja-Donsky on December 12, 1938: "My plan is" the bishop said, "that each priest should be an exemplary priest to his believers and perform his duties faithfully and most accurately. My second plan is to introduce our clergy to Catholic Action... The priest is not allowed to remove himself out of the cultural

${ }^{338}$ Ibid. 6 грудня.

${ }^{339}$ Ibid. 21 грудня.

${ }^{340}$ Нова свобода. 1938. 23 грудня.

341 Ліхтей І. Єпископ Діонисій Няраді і Карпатська Україна (листопад 1938 - березень 1939). Дзвони. 1995. Ч. 4. С. 4-5.

342 Вегеш М. Карпатська Україна (1938-1939): соціально-економічний і політичний розвиток. Ужгород, 1993. С. 69. 
work among his believers; he must take the initiative and take a lively part in this work. And there is a lot of such work everywhere: a) work of religious content, organization of religious circles, of Catholic youth, etc .; b) work in the reading room of "Prosvita", care of it and its management; c) charitable assistance to the poor; d) Organizing and conducting anti-alcohol groups... It would also be desirable for the priesthood to provide educational work of economical content... To give lectures and practical recommendations with the purpose of elevating our people to a higher economic level. It would be a good idea to set up a committee in each parish in order to allow the talented poor boys to be educated through financial aid... In Carpathian Ukraine there should be published a weekly newspaper, which could contain, in addition to political and cultural revision, valuable economic advices from the peasants... It is absolutely necessary for the people to publish as many cheap popular books as it is possible" ${ }^{343}$.

D. Njaradi actively began to implement his plan. The bishop founded "The Society of Greek Catholic Priests", headed by Y. Stanynets, and S. Sabol became a secretary. He maintained contact with the clergy with the help of the "Bulletin of the Mukachevo Eparchy in the Czechoslovak Republic", the first issue of which came to light on January 1, 1939 in Khust. There were five issues in total. The "Bulletin" published the bishop's messages to priests and to believers, information about the life of the eparchy, and so on. S. Sabol published the "Missionary Calendar". These editions were published in the premises of the state printing house in Khust.

In the late 1930s, two Greek Catholic teachers' seminaries greatly expanded the number of students and gave from 200 to 250 graduates each year. In addition, a Greek Catholic seminary was successfully operating in Uzhgorod to prepare priests. On February 1, 1939, on the advice of A. Voloshyn's government, Bishop D. Njaradi transferred the Uzhgorod Theological Seminary to Olomouc. Basilian monk M. Kalynets was appointed as its rector ${ }^{344}$.

On March 10, 1939, D. Njaradi signed a decree for the priests to celebrate the Soim of Carpathian Ukraine in the churches: "In a special way, I charge and assign that on the day of the opening of the Soim - the exact date will be announced by the radio - in all parishes of our eparchy in the autonomous territory of the Carpathian Ukraine, the spirit fathers should take the God's Service; believers and local governments must be informed in advance. Equally, I charge that, on that bright occasion, all the bells in our

\footnotetext{
${ }^{343}$ Нова свобода. 1938. 13 грудня.

344 Ліхтей І. Єпископ Діонисій Няраді і Карпатська Україна (листопад 1938 - березень
} 1939). Дзвони. 1995. Ч. 4. С. 5. 
churches be called in the evening (the last evening before the opening of the Soim - Aut.) and on the very day of the opening of the Soim after the God's

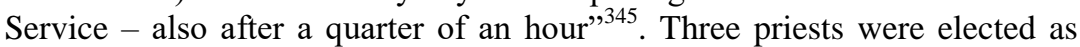
ambassadors of the Soim of Carpathian Ukraine - K. Fedelesh, A. Dovbak and Y. Stanynets. V. Grenja-Donsky wrote about the latter that he is "a beloved priest, a famous preacher and a famous writer of ours" ${ }^{\$ 346}$.

In Carpathian Ukraine, there were 140 Orthodox parishes with five monasteries, two of which were female and one was located in Prešov Region $^{347}$. In total, there were 155.000 Orthodox in the region. According to P.R. Magocsi, "the Orthodox bishop... did not support Voloshyn's government. Orthodox population, which was instilled in love with everything Russian, could not adopt the Ukrainian ideology of the Khust government" ${ }^{348}$. We believe that V. Shandor is more correct, when he states that "the struggle began with the merit of Bishop Savathy in the Orthodox Church. Savathy appeared in Carpathian Ukraine and served the Church services. The Orthodox Church in the Carpathian Ukraine belonged to the jurisdiction of the Serbian Orthodox Church, while Savathy belonged to the Moscow Church, which was not recognized in Czechoslovakia. It is obvious that Savathy's purpose was to make a revolt",349.

Minister of Interior Affairs of Carpathian Ukraine Y. Revai received a representative of the "German Information Bureau" during his stay in Prague on December 4, 1938, stating to him: "Hostile propaganda spreads gossip that there is persecution in Carpathian Ukraine on political or religious background, including persecution of the Orthodox population. These rumors are fictional. There are no prosecutions in Carpathian Ukraine. All citizens, regardless of political beliefs or religious affiliation, are equal against the law» ${ }^{350}$. On November 23, 1938, A. Voloshyn received Archbishop Savathy, "a conversation with whom lasted 40 minutes and concerned the affairs of the Orthodox Church in the Carpathian Ukraine. Archbishop Savathy, after speaking with the Prime Minister, received the editor of "Nova Svoboda" and expressed a great pleasure that the Prime Minister treats the needs of the Orthodox Church in the Carpathian Ukraine

345 Документи свідчать. Ужгород: Карпати, 1985. С. 120.

${ }^{346}$ Гренджа-Донський В. Щастя і горе Карпатської України: Щоденник. Мої спогади / Ред. Д. М. Федака. Ужгород: ВАТ «Видавництво «Закарпаття», 2002. С. 223.

${ }^{347}$ Стерчо П. Карпато-Українська держава: 3 історії визвольної боротьби карпатських українців у 1919-1939 роках. Торонто, 1965; Львів: За вільну Україну, 1994. С. 86.

348 Магочій П. Р. Формування національної самосвідомості: Підкарпатська Русь (1848-1948). Ужгород, 1994. С. 115.

349 Шандор В. Спомини. Т. 1. Карпатська Україна. 1938-1939. Ужгород: МПП «Гражда»; Карпатський Союз, 1996. С. 257.

${ }^{350}$ Нова свобода. 1938. 4 грудня. 
with full understanding and favor" ${ }^{351}$. On November 28, A. Voloshyn received a new bishop of the Orthodox Church, V. Rajich from Mukachevo, who "made a statement of loyalty to the Prime Minister of the CarpathoUkrainian state and its authorities" ${ }^{\text {352 }}$. On December 21, A. Voloshyn was visited by the Serbian Orthodox Metropolitan Josyph, accompanied by Bishop V. Rajich and Archimandrite O. Kabaliuk. The delegation sent congratulations from Havrylo, the Patriarch of the Orthodox Church. Metropolitan Josyph assured A. Voloshyn that the Orthodox Church would be loyal to the authorities of the Carpathian Ukraine and would not interfere with national affairs.

Thus, the government of A. Voloshyn went on a rapprochement with the leadership of the Orthodox Church, which began to bring the first positive consequences. In the village of Kopashniovo during the celebration at St. Michael's Church, the Orthodox Archbishop urged to pray for "Our Godkeeping Carpathian Ukraine and its Government"353. Representatives of the Orthodox Metropolis, along with Greek Catholic Bishop D. Njaradi, participated as honorary guests in the Carpathian Sich congress in Khust ${ }^{354}$. Among the issues discussed on December 29, 1938, at the meeting of the Synodal Committee of the Ukrainian Orthodox Metropolis of the Carpathian Ukraine were the following: "The Ukrainian Orthodox Church in the service of the revival of the Carpathian Ukraine and the development of church organization and our relation to other churches" ${ }^{355}$. These facts are a proof that the leadership of the Orthodox Church in the Carpathian Ukraine was loyal to A. Voloshyn's government and the policy pursued by his office.

In the Transcarpathian territory, occupied by Hungary, Olexandr Stoyka was the Greek Catholic Bishop of the Mukachevo Eparchy. A highly educated and experienced man, he pursued a vague and inconsistent policy, often changing his views. On October 26, 1938, when A. Voloshyn became a Prime Minister of Subcarpathian Rus, during a prayer service, Bishop O. Stoyka called him "the father of the people" 356 . In the first half of March 1939, the bishop stated on the radio: "...The place of the Rusyn people can only be in Hungary, where for a thousand years it has shared good and evil with the fraternal Hungarian people... And now, in these

${ }^{351}$ Ibid. 27 листопада.

352 Ibid. 30 листопада.

353 Палінчак М. М., Болдижар М. М. Релігія і церква на Закарпатті в 20-30-х pp. Нариси історії Закарпаття. Т. 2. Ужгород, 1995. С. 447.

${ }_{354}$ Карпатська Січ. Матеріали наукової конференції. Ужгород, 1996. С. 104.

${ }^{355}$ Нова свобода. 1938. 29 грудня.

${ }^{356}$ Бенько Н. Міжконфесійні відносини на Закарпатті в політичних подіях 1938-1949 pp. Науковий збірник Закарпатського краєзнавчого музею. Випуск другий. Ужгород, 1996. C. 104. 
hours, when the heroic army of St. Stephen's Hungary is approaching the Carpathian Mountains to free us, the Ruthenians, from the desperate hell, we see in this the holy will of the good God who cares for the fate of people and nations. These honved-heroes... with brotherly love will unite with our Rusyn soldiers, to provide respect for the faith and church of the Rusyn people forever, to protect our sacred traditions and the possibility of material life, decent to a human. Accept the honveds with trust love" ${ }^{357}$. O. Stoyka concluded his speech with the words: "Long live our millennial homeland Hungary, long live our beloved Regent and long live our dear Rusyn

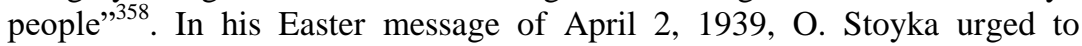
glorify the Hungarian invaders and to give them with pleasure the wealth of the land ${ }^{359}$.

On June 13, 1939, O. Stoyka took an oath of allegiance to Hungary: "I, Dr. Stoyka Olexandr, as it fits to a bishop, I swear by the holy Gospel that I will be a loyal supporter of the Regent of Hungary, and I promise that I will neither directly nor indirectly participate in matters that are contrary to the interests of Hungary. God help me!" 360 . However, he soon became convinced that the Hungarian authorities were in a double game. In doing so, they discredited themselves in the eyes of the bishop. According to modern researchers $^{361}$, O. Stoyka made every effort to protect his people. His courageous speech did not allow degrading the prelate rector Olexandr Khira, who had been ignored by the new Hungarian authorities for a long time in the seminary. He also made sure that the leadership of the seminary remained in the hands of the priests-narodovtsi. He filled the student places in the seminary with peasant boys and took care of the uplift of the religious and cultural life of the people. Under his leadership, the official body of the Mukachevo-Presov Eparchy "Dushpastyr", the magazines "Blahovisnyk" and "Missionary Bulletin" had been publishing. However, in spite of this, Bishop O. Stoyka undoubtedly did everything to accelerate the occupation of Carpathian Ukraine by Hungary.

Bishop Vladymyr Raic appointed hegumen Aurikius as the administrator of the Orthodox parishes of the western part of Transcarpathia, occupied by the Hungarian troops. Bishop Raic was offered to accept the Hungarian citizenship, but he refused. In this regard, the Hungarian Ministry of Cults

\footnotetext{
${ }^{357}$ Документи свідчать. Ужгород: Карпати, 1985. С. 122.

${ }^{358}$ Ibid.

359 Ibid.

${ }^{360}$ Ibid.

361 Бенько Н. Міжконфесійні відносини на Закарпатті в політичних подіях 19381949 pр. Науковий збірник Закарпатського краєзнавчого музею. Випуск другий. Ужгород,
} 1996. C. 107. 
stated that V. Raic was a subject of another country and therefore he could not be recognized by the government as an authorized to perform the functions of bishop in their state. He was interned as a person unreliable to the Hungarian authorities. Hegumen Feofan Sabov was appointed in his place, but soon he was also removed ${ }^{362}$. A famous researcher of the church history, O. Danko wrote: "The general impression of the population of Transcarpathia about the attitude of the Hungarian authorities to the Transcarpathian churches can be summarized in the simplified form: the Hungarian authorities favored the Greek Catholic Church, and their attitude towards the Orthodox was hostile, or at least it acted as a stepmother... The Orthodox Church of Transcarpathia... passed a way from the state of the church, persecuted at the very beginning, to the state of the church,

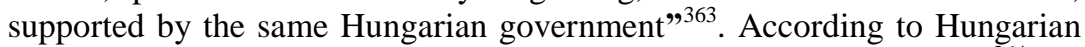
statistics, in 1940 in Transcarpathia there were 110 thousand Orthodox ${ }^{364}$.

On March 15, 1939, Hungarian troops began the occupation of Carpathian Ukraine. After a while, mass repression began, which did not bypass the representatives of the church, and it did not matter to which confession the particular priest belonged. P. Chuchka and E. Shwed proved: "Archival materials testify that the attack of the Hungarian authorities on the Ukrainian idea in Transcarpathia did not stop in the interwar years. Some of them illustrate the dynamics and technology of this attack, reveal the specialty of the kimmel-garitov services, naming specific individuals who were approved for physical execution by the Hungarian repressive bodies on the eve of World War II, in particular from the autumn of 1938 to the spring of 1939 " 365 . These scientists have found two archival documents called "List of the Ukrainians who have done a great deal of harm to both the Hungarian and the Rusyn people" and "List of the Ukrainians who tried to harm the Hungarian and Hungarian-Rusyn people", which include the names of 140 people. All of them were considered fierce enemies of Hungary and had to be eliminated. The researchers proved that the lists were drawn up on

362 Хланта О. Деякі питання керівництва Мукачівською єпархією православної церкви в Закарпатській Україні у 1939-1944 рр. Науковий збірник Краєзнавчого музею. Випуск 2. С. 103-119.

363 Данко О. Угорська політика відносно православної церкви на Закарпатті в 19391944 рр. Культура Українських Карпат: традичії і сучасність. Матеріали міжнародної наукової конференції. Ужгород, 1994. С. 362.

364 Маркусь В. Нищення греко-католицької церкви в Мукачівській єпархії в 1945 1950 pр. Відбитка із Збірника присвяченого памяті 3. Кузелі. Записки НТШ. Т. СХІХ. Париж, 1982. С. 5.

365 Чучка П., Швед Е. На шляху до Ковнера - 42. За Украӥнське Закарпаття: Дослідження, статті, спогади / Упор. В. Маркусь, В. Худанич. Ужгород: Гражда, 1994. C. 38 . 
November 10, 1938, that is, immediately after the end of the Vienna Arbitration and long before the invasion of the Hungarian troops into the territory of Carpathian Ukraine.

The names of five clergymen - Bulyk, V. Lar, O. Khira, S. Pap and Y. Stanynets - were in that lists ${ }^{366}$. It should be added that only well-known people among the general population are listed. Time has shown that during 1939-1942 they all went through Hungarian prisons and camps. The list does not include the name of D. Njaradi, who was known far beyond Transcarpathia. However, despite the great popularity of the bishop, "two days after the occupation of Carpathian Ukraine, the government of the Hungarians placed Bishop Njaradi in his own apartment in Khust under strict gendarmic supervision, prohibiting him from leaving the house and meeting people. The brutal behavior of the gendarmerie and other Hungarian governmental authorities has made Bishop Njaradi humiliated. Only later Angelo Rotta, the Apostolic Nuncio in Budapest, helped the bishop and his secretary Fr. Reshetyl to leave for Rome" ${ }^{367}$.

The lack of archival sources regarding the Horthyst repression against priests is somewhat complementary to eyewitness accounts. They testify to the horrific terror committed by the Hungarians: "The middle of the liturgy. Without finishing the church service, Fr. Kupar was seized, his chasuble was removed and he, as a criminal, was taken out of the church... The arrested people were driven into the woods. They stopped at a lawn. One attempted to flee - that was Fedir Rozniychuk - but he was shot dead. The others got bullets into their feet, and all the wounded fell to the ground. Raging sadists in the wild fury were pulling out the eyes of the living people, cutting off their lips, tongues, tearing their bellies. Inhuman cries, moaning, yelling were rushing over the forest. These people died in a great martyrdom. In the Hutsul region, they are called "martyrs of Kvasiv" 368 . The priest Y. Stanynets recalled: "I was tortured and judged, because "I took part in an underground organization that aimed to drive the Hungarian occupiers from Transcarpathia". The judges and investigators of my "case" stated this... By beating, bullying they tried to "knock out" a confession. Our judges did not delve into the case" ${ }^{369}$. Greek Catholic priest Pohorilyak from the village Ternovo in the Tyachiv region was sentenced to five years in prison ${ }^{370}$. An active participant in the events of 1938-1939 in Carpathian Ukraine, priest

${ }^{366}$ Ibid.

367 Шандор В. Спомини. Т. 1. Карпатська Україна. 1938-1939. Ужгород: МПП «Гражда»; Карпатський Союз, 1996. С. 257.

${ }^{368}$ Карпатська Січ. Матеріали наукової конференції. Ужгород, 1996. С. 257.

${ }^{369}$ Ibid. C. $74-75$.

${ }^{370}$ Ibid. C. 75. 
S. Pap went through torture in Khust prison and concentration camp in Kryva. In 1942, he was sentenced for the second time. The verdict stated: "...the defendants proclaimed that Transcarpathia has always been a Ukrainian territory, and will remain so, in connection with what Transcarpathia should, if necessary, have to break away from Hungary and join Ukraine with an armed uprising and revolutionary path"371.

The pro-Hungarian priests assisted the horthysts in their acts of repression. Such, in particular, was Y. Maryna. S. Pap recalled: "He is a Greek Catholic priest, professor and vice-rector of the Theological Seminary in Uzhgorod, his behavior was too coarse and arrogant. None of the students loved him. He was not an example of a good priest to them. He was a Hungarian spy in the priesthood... And now he is here to look at the death of the last victims of Hungarian violence" ${ }^{\text {372 }}$. Bishop O. Stoyka helped many to avoid detention and saved their lives.

The overwhelming majority of the population of Carpathian Ukraine was of Greek Catholic faith. From mid-November 1938 to mid-March 1939, the Bishop of Križevci, D. Njaradi, who had a clear pro-Ukrainian orientation, fulfilled the duties of apostolic administrator in the land. The government of the Carpathian Ukraine has done everything to prevent conflicts between believers of the Greek Catholic and Orthodox denominations. The Orthodox Church, which belonged to the Serbian Orthodox Metropolis, was loyal to A. Voloshyn's government. The bishop of Mukachevo, O. Stoyka, who stayed in the territory occupied by Hungary, served the invaders faithfully, encouraging them to occupy Transcarpathia completely. However, during the occupation he acted less actively, disappointed with the ambiguity of Hungarian politics. With the occupation of Transcarpathia by the Hungarian troops, a brutal repressive regime was established in the land, which had affected the clergy of both denominations.

\footnotetext{
${ }^{371}$ Карпатська Січ. Матеріали наукової конференції. Ужгород, 1996. С. 78.

${ }^{372}$ Ibid. C. 113
} 